\title{
Erratum to: Characterizing slope morphology using multifractal technique: a study from the western continental margin of India
}

\author{
Bishwajit Chakraborty $^{1}$ - S. M. Karisiddaiah ${ }^{1}$. \\ A. A. A. Menezes ${ }^{1}$ - K. Haris ${ }^{1}$ - G. S. Gokul ${ }^{1}$. \\ W. Fernandes ${ }^{1} \cdot$ G. Kavitha ${ }^{1}$
}

Received: 31 March 2015/Accepted: 31 March 2015/Published online: 8 April 2015

(C) Springer Science+Business Media Dordrecht 2015

\section{Erratum to: Nat Hazards (2014) 73:547-565 \\ DOI 10.1007/s11069-014-1085-8}

The article has been published in Volume 73: pp. 547-565 (2014).

It belongs to the Special Issue:

The Role of Fractals in Seismology.

The online version of the original article can be found under doi:10.1007/s11069-014-1085-8.

Bishwajit Chakraborty

bishwajit@nio.org

1 CSIR-National Institute of Oceanography, Dona Paula 403 004, Goa, India 